\title{
Competitive Public Procurement during COVID-19: The Unique Political and Policy Experience of the United States
}

\author{
Clifford McCue Emily Boykin Eric Prier
}

\begin{abstract}
COVID-19 appeared during one of the most turbulent political environments in U.S. history. This research documents how political polarization during a presidential election year coincided with an incoherent national policy and procurement response to the COVID-19 pandemic, and empirically examines the competitive nature of pandemic-related public procurement contracts across the 50 states based on partisan control of state governments.
\end{abstract}

\section{Keywords}

Disaster Spending; Partisan Politics; Public Procurement; Full and Open Competition

The operations of the federal government will be most extensive and important in times of war and danger; those of the State governments, in times of peace and security.

James Madison

\section{Introduction}

Responsible for the catastrophic loss of life and substantial impact on the global economy, the SARS-CoV-2, commonly known as COVID-19, drives much of the current political, economic, and social agenda. While the effects of the COVID-19 pandemic vary across nations, its effect on the United States (U.S.) is unique and characterized by a complicated federal system of government and partisan politics (Kettl 2020; Rocco et al. 2020; Xu et al. 2020; Bekker et al. 2020). Adding to the complexity of dealing with the virus, including slowing disease transmission, maintaining an effective healthcare system, and protecting front-line workers, the U.S. suffered economic damage during one of the most divisive presidential elections in U.S. history (see for example, ShockleyZalabak \& Morreale 2020). Moreover, 2020 saw rising social unrest at government's treatment of minorities (Towler, Crawford \& Bennett 2020), coupled with increasing distrust of politicians by Americans - all of these developments suggested that there were growing questions about whether the government can effectively combat the virus (Pew 2019, Cooper 2018; Van de Walle et al. 2008). ${ }^{1}$

In this heavily politicized social environment, the federal government addressed the COVID-19 crisis with Congress passing the largest economic stimulus package in U.S. history - the $\$ 2.2$ trillion Coronavirus Aid, Relief, and Economic Security (CARES) Act on March 27, 2020 (see other coronavirus-related Congressional acts in Shearman \& Sterling 2020; timeline adopted from AJMC 2020). The CARES Act provided direct economic relief to American families ( $\$ 300$ billion in

\footnotetext{
${ }^{1}$ The Pew Research Center bears no responsibility for the analyses or interpretations of the data presented here. The opinions expressed herein, including any implications for policy, are those of the author and not of Pew Research Center.
} 
one-time cash payments), aid to businesses through the Paycheck Protection Program ( $\$ 350$ billion in original funding, and later increased to $\$ 669$ billion), tax incentives and loans to businesses ( $\$ 500$ billion), and assistance to state, local, and tribal governments navigating the impact of the COVID-19 outbreak ( $\$ 339.8$ billion).

Indeed, while the CARES Act helped stabilize the economy, the federal government failed to take the lead in addressing the health and safety needs of the nation, and an intergovernmental nightmare ensued (Kettl 2020). During a press conference on April 10, 2020, President Trump said that he wished to "allow governors to make decisions without overruling them", and this policy declaration resulted in the federal government - along with state and local governments competing to acquire pandemic-related supplies and services such as personal protection equipment (PPE) and medical equipment (Gerstein 2020). When nearly all governments simultaneously tried to acquire essential goods and services, demand spiked. As a result, prices for supplies like N95 masks rose quickly; corruption and outright supplier fraud increased; and ultimately some indispensable goods and supplies were either not received in time or not received at all (Atkinson et al. 2020; Vecchi et al. 2020). A point was reached where, according to the Chicago Sun Times (April 15, 2020), Illinois Governor Pritzker purchased millions of Chinese gloves and masks and chartered a plane to bring them to his state. Things were so dire that Pritzker felt it important to keep the details of the procurement secret because he feared the cargo might be seized by the Trump administration and diverted into the federal stockpile.

These conditions raise fundamental questions, not only about government transparency and accountability, but also about procuring in times of a global pandemic. This research examines the core public procurement norm of full and open competition during the COVID-19 emergency situation. Given the extremely partisan environment in which national policy played out, it is hypothesized that competitive procurement procedures were relaxed in the face of growing pandemic-related chaos. As a result, observers may infer that the U.S. federal government procurement strategy may contribute to American's growing distrust in government institutions, especially in light of the incoherent federal response that ultimately helped fuel the disastrous effects of the deadly virus (Rocco et al. 2020; Grossman et al. 2020; Xu et al. 2020; Bekker et al. 2020; see CDC 2020 for an updated number of virus casualties).

The purpose of this research is to explore the relationship between partisan politics, public trust in government, and how the federal government contracted for COVID-19 supplies and services. To directly measure if COVID-19 competitive contracting practices differed from those procured under normal circumstances, all specified COVID-19 contracts are compared to all contracts for the fiscal year 2020 (October 1, 2019 to September 30 , 2020 - FY2020). To assess if the political climate during this past year may have resulted in differential competitive contracting practices, COVID-19 related contracts are linked to the state in which the federal contracts are performed, and this linkage is then evaluated based on political party control of the state legislature and governor's mansion.

\section{Partisan Politics, Public Trust, and the COVID-19 Pandemic}

Public trust in government is employed herein as an evaluative tool and is associated with ideological partisan politics. Analyzing public trust can unveil potential consequences for governance capabilities and, specifically, purchasing during the COVID-19 crisis (Chanley et al. 2000; Rudolph \& Evans 2005; Gauchat 2012; see also the GHSI 2019 or WHO 2017 index). While 
issues of public trust and perception of government are not unique to the U.S. (see Keele 2005), 2020 was a unique year given the electoral circumstance and the increasingly divisive nature of partisan politics. Moreover, partisanship colors the perceptions of the electorate. For instance, it remains true that confidence in government is relatively higher for Americans belonging to the party that controls the White House, though it is particularly aggravated during Republican rule (see the Miller-Citrin debate on partisan politics and its impact on public trust in government; Miller 1974a; Miller 1974b; Citrin 1974). However an April survey administered by the Pew Charitable Trusts notes that not even a Republican controlled Senate, which helped pass the CARES Act, could boost public trust in the Trump administration's handling of COVID-19 - nor could the stimulus package itself diminish negative perceptions of the economy, which was manifest in high unemployment, small businesses closing, and the middle-class experiencing food insecurity (Pew 2020a).

Applying findings by Nyhan (2020) and Swire et al. (2017) suggests that the leader phenomenon might help describe the clear ideological polarization of the government's handling of the economy during the pandemic, where Republicans proved far more optimistic of their party's decisions regarding the coronavirus relative to Democrats (Nichols 2017; Drezner 2017; Pew 2020a; Pew 2020b). Indeed, when Americans were asked their thoughts on President Trump's assessment of the virus' risk, approximately $73 \%$ of respondents belonging to the president's party believed the president had "gotten the risks about right" compared to only $8 \%$ of Democrats. In fact, $55 \%$ of Democrats believed the president had "not taken the risks seriously at all", whereas only approximately 3\% Republicans shared those same beliefs (Pew 2020b).

While public trust in how the U.S. federal government spends tax dollars is at an all-time low (OECD 2020), fluctuations persist in times of administrative shifts, election years, and emergent crises (Nyhan 2020; Klein 2020). In the face of disaster-related events such as hurricanes, Miller (2016) finds that public confidence in public institutions decreased. One exception was a poll taken a month after the September 11, 2001 terrorist attack which showed that for the first time since 1970, a majority of both Democrats and Republicans trusted the federal government to do what is right "just about always" or "most of the time" (Chanley 2002; Pew 2020a). Thus, public trust in governmental institutions is correlated with the type and effect of the disaster, among other variables such as political identity or ideological differences (see, for other examples, Reinhardt 2019; Lang \& Hallman 2005; or Poppo \& Schepker 2010).

For COVID-19 specifically, geography likely contributed to partisan politics. Consider that the pandemic first flared in urbanized cities dominated by relatively more liberal voters and Democratic party-controlled state offices, while rural states dominated by the Republican political party did not experience the impact of COVID-19 until months later. The combination of heightened politics during a presidential election year; a deadly virus; and the presence of a biasconfirming media ecosystem, further exacerbated the partisan polarization (Hanitzsch et al. 2018; Nyhan 2020; Kiousis 2001). Consequently, and for many reasons, the U.S. exhibits low levels of public trust in the press, especially during the Trump administration's callouts of "fake news" and the evils of science, the embrace of "magical thinking", and propagating media misconceptions and misinformation (Atkinson et al. 2020; Hanitzsch et al. 2018; Nyhan 2020; Kiousis 2001). As a result, a recent survey found that half of Republicans thought news media exaggerated the risks of the virus to some degree or another (Pew 2020a). 
In sum, the extreme partisan atmosphere that was intensified during an extraordinary election year, not only shaped public perception of the federal government's capabilities and inadequacies, but also likely shaped its decision-making (see Huntington 1981; Woodard 2012). The following section illustrates how public procurement was conducted within this environment.

\section{Supply-Chain Nightmares and Intergovernmental Ineffectiveness}

According to the Organization for Economic Co-operation and Development (OECD 2009), to promote public trust in how public funds are managed, public procurement must "include elements of transparency, good management, prevention of misconduct, as well as accountability and control" including "an overarching obligation to treat potential suppliers and contractors on an equitable basis" (p. 127). If governments follow these fundamental guiding principles, citizens and businesses alike will be more confident that governments are good stewards of public resources. During the COVID-19 crisis, however, it is likely that elements of these norms were undermined to some degree. For example, consider the intergovernmental stockpiling of procured medical goods and supplies, and the supply-chain vulnerabilities that evolved during the pandemic.

COVID-19 exposed substantial weaknesses of just-in-time procurement supply-chain management, and one need look no further than the Strategic National Stockpile (SNS) failure in distributing proper medical supplies to health professionals, particularly N95 face masks and ventilators (Gereffi 2020; Handfield et al. 2020). Historically, the SNS's role was to buffer immediate shortages of critical medical supplies and also supplement state and local supplies during crises - although it's effective function arguably rests on the assumption that states have properly managed their own stockpiles (Esbitt 2003). As states attempted to balance the need for a vigorous economy and a healthy public, administrators began pushing for a greater role for federal policymakers to help overcome state revenue shortfalls, massive cuts to essential policy areas, and the lack of appropriate infrastructural processes to carry out necessary procurement actions (Clemens \& Veuger 2020; Bekker et al. 2020; Gordon et al. 2020; Chernik et al. 2020; Clemens 2012; CBPP 2020; see LAO 2020 for the state of California as an example).

Leaving aside issues associated with the individual sovereign states' obligations to protect their own citizens, there is little debate that both the federal government and the states had inadequate stockpiles leading up to the pandemic. The federal government has, for a long time, exhibited its commitment to a just-in-time supply chain strategy that tends to maximize vendor corporate shareholder value (Lazonick \& Hopkins 2020). This federal strategy led the Trump administration to falsely claim to have inherited an "empty" stockpile yet fail to modernize expired equipment and procure necessary supplies in the three years leading to the pandemic (Gore 2020; PBS 2020). While this failure may have partly been a consequence of departmental changes, where the Centers for Disease Control and Prevention (CDC) relinquished its management duties to the Department of Health and Human Services in 2018, signs also point to an ineffective and nepotistic administration. Not only did the administration oversee such departmental changes, but the senior advisor and son-in-law of the president conceptualized the SNS as solely a federal stockpile after a long history of shared relations, thus formally downplaying the obligatory federal role in assisting state and local efforts based on previous promises (Weixel 2020; see PHE 2020 for an updated definition). 
If one of the major tenets of good procurement practice is managing and coordinating critical supply-chain vulnerabilities at all levels of government (Schapper et al. 2006), when both state and federal institutions refuse to share the burden, rational efforts to respond in a crisis are inefficient. Consequently, increased economic and resource costs rose as authorities attempted to procure essential supplies which require a rigorous and timely federal certification, where highrisk suppliers were granted multimillion-dollar contracts (PBS 2020; WSJ 2020). For example, Philips Respironics has historically been unsuccessful in fulfilling government contracts, yet the federal government continued to funnel millions of dollars to unfilled contracts procuring critical goods and supplies during a health crisis (PBS 2020; see also NYT 2021). Reliance on failed procurement procedures and management processes surely diminishes public trust and increases supply vulnerability risks. Even as the country seeks some relief from the virus at the start of administering highly effective vaccinations across the country, supply-chain and distributional complications abound. These include the lack of intense cooling systems to store the medicine and the over-reliance on military operational help that continually threaten logistical realities that will impact its effective distribution and intended utilization (Locht 2020; Alexander 2020).

While there have been numerous warnings about the threat of infectious disease for a long time (see Garrett 1994; Central Intelligence Agency 2000), prolonged federal emergency mismanagement and reliance on international suppliers whose loyalty would default to their home country was the backdrop for the U.S. shortage of ventilators and other medical supplies during COVID-19 (PBS 2020; CNN 2020; see, for example, GAO 2008). Yet, all levels of government were ill-prepared and relatively ineffective in procuring needed supplies. As a consequence, it is hypothesized that the federal government had to ameliorate this situation by relying on nontraditional procurement procedures.

\section{Full and Open Competition in Pandemic-Related Public Procurement}

Transparency and competition are hallmarks of public contracting in both Europe and the U.S. Indeed, the institutionalization of voluntary ex ante transparency notices in Europe attest to the centrality of these notions (see Prier, McCue, \& Boykin 2021 forthcoming). Moreover, the European Union directives on full and open competition (see for example, Directive 2014/24/EU) are consistent with what the U.S. federal government requires, with certain limited exceptions (see FAR subpart 6.2 and 6.3). Consider that for all contracts exceeding $\$ 250,000.00$ (FAR 1.404), federal agencies must use a formal tendering process that requires publishing contracting opportunities at least fifteen (15) days before the issuance of a bid or solicitation and at least thirty (30) days for businesses to respond to those opportunities (Competition in Contracting Act, 41 U.S.C. 253; also see FAR Subpart 6.1"Full and Open Competition”). For purchases below $\$ 250,000$, federal agencies can use the simplified acquisition procedure (SAP). The SAP allows federal agencies to use informal quotes and shorter competition procedures for purchases below the established threshold (FAR 13.500(c)). 
For example, quotes may be submitted orally and quoted prices may be directly compared by contracting officers rather than by conducting formal negotiations. Therefore, vendors may be chosen directly (i.e. non-competitively) by a contracting officer. ${ }^{2}$ Although SAP allows federal agencies to directly contract with certain economic operators, federal agencies are not mandated to use the SAP if the agency believes it can acquire the needed goods and services through a formal tendering process.

As noted above, COVID-19 occurred in a polarized political environment, characterized by an uncoordinated policy responses and inefficient supply-chain procurement processes administered by a distrusted federal government. With the understandable yet chaotic economic push for congressional stimulus to cope with perceived governance failures including supply-chain disruptions, it is posited herein that the relaxed federal budgetary atmosphere produced similarly lenient public procurement procedures. Specifically, in disaster-related procurement processes, it is expected that competition between vendors decreases and as a result, the overall proportion of competed contracts relative to non-competed contracts will diminish (see Seshadri 2005; Buor 2019). To examine if this expectation is empirically borne out during the COVID-19 pandemic in the U.S., the first hypothesis assesses if the proportion of competitive contracts for COVID-19 procurement is substantially different from non-COVID-19 contracts.

What follows are two analyses that examine the association between partisan state politics and competitive contracts. According to Noll and Grab, (2017) a major philosophy of Republicans (both as a national party priority and individualized ideological appeal) is government deregulation. A plausible consequence of this proposition, if true, is that Republicans would favor more deregulation in federal contracting to better reflect instantaneous supply-demand circumstances in the Hayekian spirit of informative markets (see Hayek 1945). It is hypothesized that states controlled by Republicans would be more favorable toward market pressures that result in a lower incidence of competitive contracting. To evaluate this hypothesis, statistical analyses are conducted to gauge if there is no difference between Democratic- and Republican-dominated states in the proportion of COVID-19 federal contracts issued noncompetitively. These appraisals are conditioned on both gubernatorial and legislative partisan control across the fifty states. That is, if the governor is a registered Democrat or Republican and the legislative body is primarily controlled by the same party, that state would be considered unified. For those states where there is a difference between governor party and legislative party, it would be considered a divided or split state. Data used in this study come from the U.S. General Services Administration (GSA), specifically beta.SAM.gov (SAM) ${ }^{3}$ and USAspending.gov (USA Spend). All FY2020 federal contracting data $(\mathrm{N}=5,565,306)$ were downloaded on November 8, 2020, and COVID-19 data

\footnotetext{
${ }^{2}$ For European audiences, while there is not a U.S. federal equivalent method to a dynamic purchasing agreements, framework agreements are very similar to blanket purchasing agreements (see https://www.fedmarket.com/contractors/Blanket-Purchase-Agreements--and-Basic-Ordering-Agreements-). It is important to note that the ratios of competitive to non-competitive contracts is not affected by purchasing methods.

3 Since October 2020, all U.S. federal contract awards are to be posted on SAM, which has replaced the function of the Federal Procurement Data System. SAM is similar to the Official Journal of the European Union's Tender Electronic Daily (TED) portal.
} 
$(\mathrm{N}=74,769)$ reflect published updates as of December 11, 2020. Both SPSS version 27 and $\mathrm{R}$ version 4.0.3 were used to analyze the data. While some contracts were modified or cancelled over time, the current analyses reflect only initial contract awards for all federal reported procurements greater than $\$ 3,500$ USD. ${ }^{4}$ Moreover, regardless of the purchasing method used, such as using the Federal Supply Schedule, e-procurement, purchasing cards, or informal processes, all purchasing methods are captured in the datasets used. Partisan control state data were obtained from the National Conference of State of Legislatures and population estimates for 2019 were acquired from the U.S. Census Bureau.

\section{Findings}

In order to understand and document the normal policy environment, the most recent FY2020 is baselined in terms of initial competitive contracting. Because this analysis reflects a preference for conservatively uncovering differences in competing contracting levels so as to minimize Type I errors, while the contracting data originally reported nine different categories of competition, contracts were dichotomously categorized according to competition as outlined in Table 1. Note the table also breaks out COVID-19 contracts from all contracts initiated in FY2020.

Table 1. U.S. Federal Contracting for FY 2020 and COVID-19

\section{FY 2020 Not Competitive $15.6 \%(834,998)$}

Not available for competition

Not competed

Non-competitive delivery order

Not competed under SAP
FY 2020 Competitive $84.5 \%(4,704,778)$

Competitive delivery order

Competed under SAP

Follow on to competed action

Full and open competition after exclusions

Full and open competition

\section{COVID-19 Not Competitive 24.1\% (18,241)}

COVID-19 Competitive $74.6 \%(56,528)$

The four non-competitive categories listed in the first column comprise the proportion of noncompetitive contracts, and data conform to expectations: the FY2020 "normal" procurement circumstances exhibit a baseline of $15.6 \%$ of non-competitive contracts compared to $24.1 \%$ of COVID-19 contracts falling into this category. Similarly, the large majority of all contracts during FY 2020 (which includes COVID-19 procurements comprising 1.3\% of all FY2020 contracts) were procured competitively with $84.5 \%$ of contracts baselined as competitive compared to $74.6 \%$ of COVID-19 contracts. This first analysis finds a ten percentage point higher proportion of noncompetitive contracts for COVID-19 procurement relative to baselined (normal) contracts. Given

\footnotetext{
${ }^{4}$ According to USA Spend, there are some known data limitations for COVID-19 spending. Thus, this analysis takes the data "as is" and as the best available at the time of download. Moreover, there were some apparent duplicate contract awards identified in the dataset that remain in the analyses, but since their number appeared to be minimal, there is little reason to believe that conclusive results would be systematically biased.
} 
the large Ns, this is striking evidence that the norm of competitive contracting for COVID-19 supplies and services has been relaxed. ${ }^{5}$ Although not reported in Table 1, separate calculations show proportional differences in solicitation procedures used for COVID-19 contracts compared to those for FY2020. For instance, while only differing slightly in competitive and noncompetitive simplified acquisition procedures (16.5\% of COVID-19 contracts vs. 18.1\% for FY2020), the proportion of all contracts resulting from negotiated procedures dramatically shrank for COVID19 contracts $(29.7 \%$ vs $47 \%)$.

Table 2 looks specifically at state legislative and gubernatorial party control and the extent contracts were competed within each state. The data are presented across all COVID disaster data, regardless of competition type. For both tables 2 and 3, the top portions inform about combined partisan control of state legislatures coupled with control over the executive branch. In other words, if both branches are controlled by a single party, then those states are reported in the top rows as either Democrat or Republican. If one party controls one branch and another party the other branch, then the state is labeled Split. The bottom of the two tables (labeled Gubernatorial) details which party holds the respective states' governor's office irrespective of control of the legislature.

Not specified in the tables are population totals across the categories. For the 15 states where Democrats control both branches, there is a total estimated 2019 population of 120,182,161; for the 21 states controlled by Republicans, they are estimated to have about $10 \%$ more people with a total population of 132,657,767; and the 13 states experiencing split control of both branches have a total population of $72,759,438$. The population for the 24 states with Democratic governors totals $178,019,716$ and 149,514,058 reside in the 26 states with Republican governors.

\footnotetext{
${ }^{5}$ For those interested in treating the data analyses as representing a sample, the Pearson Chi-Square $=$ 4976.317, $\mathrm{df}=1, \mathrm{p}<.001$ conditioned on the null hypothesis being true (see Thompson 1988 as to why the Yates' Continuity Correction is not reported). Due to the large Ns and the fact that the data comprise the universe of cases targeted for study, no further statistical significance tests will be run.
} 
Table 2: Demographics of COVID-19 Contracting by State Legislative and Gubernatorial Control

\begin{tabular}{lll}
\hline Party (N) & Competed Contracts (N) & Total COVID-19 Spending \\
State Control & & \\
Democrat (15) & Yes $(26,068)$ & $\$ 7,271,016,692.94$ \\
& No $(9,249)$ & $3,801,596,186.44$ \\
Republican (21) & Yes $(12,411)$ & $4,836,926,456.00$ \\
& No $(6,057)$ & $4,669,166,381.03$ \\
Split (13) & Yes $(19,661)$ & $5,147,017,073.48$ \\
& No $(2,807)$ & $4,877,354,433.42$ \\
Gubernatorial & & \\
Democrat (24) & Yes $(34,320)$ & $9,103,236,859.39$ \\
& No $(11,003)$ & $5,644,307,086.95$ \\
Republican (26) & Yes $(23,897)$ & $8,211,563,436.77$ \\
& No $(7,122)$ & $\$ 7,710,020,525.21$ \\
\hline
\end{tabular}

Source: author calculations

Data in Table 2 reveal at least three major points for the purposes herein. First, while competitive contracts were more likely procured than non-competitive contracts, there is substantial variation across the states. For example, those states with split party control between the legislative and executive branches had 7 times more competitive than non-competitive contracts performed in their states $(19,661 / 2,807)$; those states with Democrats in control had almost 3 times as many competitive versus non-competitive contracts performed in their states $(26,068 / 9,249)$; and Republican states had twice as many competitive over non-competitive contracts performed in their states $(12,411 / 6,057)$. However, when stratified by gubernatorial control, the ratios are fairly comparable at approximately three competitive to one non-competitive contracts performed in states with Democrat or Republican governors (34,320/11,003=3.12 compared to $23,897 / 7,122=3.36)$.

Looking at the data another way, these competitive versus non-competitive contracts can be examined as proportions and they reveal similar findings: states run by Democrats or states with split control were, on average, more likely to have had federal contracts to be the result of competition compared to those contracts performed in states controlled by Republicans. Indeed, $73.8 \%(26,068 / 35,317)$ of all contracts procured for delivery in Democratic-run states were competed compared to $87.5 \%$ for states with split control and $67.2 \%$ in states where Republicans controlled the two branches. Again, the large Ns confirm rejection of the second null hypothesis.

The data reported in the last column suggest clear partisan differences in total spending amounts across the states as well. For instance, total COVID-19 competitive contract spending in Democrat 
controlled states was nearly twice the non-competitive contract spending while for both split and Republican controlled states, there were nearly equal amounts of COVID-19 competitive and noncompetitive contract spending performed in these states. When considering which party holds the governor's seat, the competitive/non-competitive spending ratios are 1.61 for Democrats and 1.07 for Republicans.

Table 3: COVID-19 Contracting by State Legislative and Gubernatorial Control

\begin{tabular}{|c|c|c|c|}
\hline$\underline{\text { Party }}$ & Competed & Spend/Per Capita & Spend/Per Contract \\
\hline
\end{tabular}

\section{State Control}

\begin{tabular}{lllll} 
Democrat & Yes & $\$ 60.49$ & $\$ 278,924.99$ & 21.69 \\
& No & 31.63 & $411,027.80$ & 7.69 \\
Republican & Yes & 36.46 & $389,728.98$ & 9.35 \\
& No & 35.19 & $770,871.12$ & 4.56 \\
\multirow{2}{*}{ Split } & Yes & 70.74 & $261,788.16$ & 27.02 \\
& No & $\$ 67.03$ & $\$ 1,737,568.37$ & 3.85
\end{tabular}

\section{Gubernatorial}

$\begin{array}{lllll}\text { Democrat } & \text { Yes } & \$ 51.14 & \$ 265,245.83 & 19.28 \\ & \text { No } & 31.71 & 512,978.92 & 6.18 \\ \text { Republican } & \text { Yes } & 54.92 & 343,623.19 & 15.98 \\ & \text { No } & \$ 51.57 & \$ 1,082,563.96 & 4.76\end{array}$

Source: author calculations

a This ratio is per 100,000 people

Table 3 stratifies COVID-19 data differently. Looking at the first two rows of the total number of competed contracts procured for states controlled by the Democrat party, the average dollars spent per capita is $\$ 60.49$ for competed contracts or nearly twice that of the $\$ 31.63$ average for noncompetitive contracts. Further, the average dollars spent per competed contract is $\$ 278,925$ versus $\$ 411,028$ for non-competitive contracts; and the number of competed contracts/per capita in Democrat states is 21.69 which is about three times the 7.69 figure for non-competitive contracts. The bottom of the table reports similar results for states with Democrat governors: the average competitive dollars spent/per capita is $\$ 51.14$ versus a non-competitive average of $\$ 31.71$; the average spend/per competed contract is $\$ 265,246$ versus $\$ 512,979$ for non-competitive contracts; and the number of competed contracts/per capita in Democrat states is 19.28, which again is about 3 times the 6.18 figure for non-competitive contracts. 
All of the table data can be transformed into ratios for stratified comparison purposes. For example, transforming data at the top of the table reveals the competitive versus non-competitive Democrat spend/per capita ratio is $1.91(\$ 60.49 / \$ 31.63)$; a ratio value of 0.68 for spend/per contract $(\$ 278,925 / \$ 411,028)$; and a ratio of $2.82(21.69 / 7.69)$ for competitive versus non-competitive contracts/per capita. Consider how these numbers for Democrat states are distinguished from those states controlled by Republicans with a nearly even competitive versus non-competitive spend/per capita ratio of $1.04(\$ 36.46 / \$ 35.19)$; a ratio of 0.51 for spend/contract; and a ratio of 2.05 contracts/per capita ratio. Results in the lower part of the table reporting gubernatorial control reveal similarly divergent partisan ratios: spend/per capita ratios of 1.61 (for Democrats) and 1.07 (for Republicans); spend/contract ratios of 0.52 (D) and $0.32(\mathrm{R})$; and contracts/per capita ratios of $3.12(\mathrm{D})$ and $3.36(\mathrm{R})$, respectively.

No matter how partisanship is measured (state or gubernatorial control), this exploratory data analysis suggests a partisan component to COVID-19 federal contracting and spending. Indeed, the bottom of Table 3 shows that over three times as much money per non-competitive contract was spent compared to the average amount spent for competitive contracts in states with a Republican governor. This is in contrast to Democrat states where less than twice the average contract amount was non-competitive versus competitive.

\section{Conclusion: What Not to Do in a Pandemic}

The federal and state relationship in the United States, and the intergovernmental responses towards the virus, is an entirely unique experience from that of European countries (Cairney \& Wellstead 2020). This research illustrates that, in contrast to the experience of many European countries, the lack of a coherent or coordinated policy response at the federal level has asymmetrically affected various states at all levels of government, and will likely have an impact on public trust in government institutions across the U.S. The public perception of this uneven and unique response to COVID-19 challenges demonstrates that in an exceptional election year characterized by hyper-partisanship, public policy will inevitably be interpreted through a web of political narratives that will likely impact how emergency preparedness and supply-chain failures will be viewed. This is also true for the federal procurement decisions detailed herein that were intended to mitigate the virus.

This research focused on how the partisan and political environment provides a backdrop by which COVID-19 contracts procured by the federal government were empirically distributed across the states. Although the analyses do not directly measure if politics drove how the federal government procured goods and services under the Trump administration, there is enough evidence to consider the possibility that partisan politics did at least contribute to differences in the distribution of competitive contracts. By baselining all pandemic-related contracts to the most recent fiscal year, this analysis has confirmed that competition between vendors decreased to potentially prioritize faster decision speeds and fulfill contracts, but the data show that during COVID-19, such effects are felt unevenly across states depending on partisan control.

Taken together, these findings call for further research. In terms of addressing some of the problems associated with the federal response to the COVID-19 pandemic, future investigations could examine ways the federal government can more fully promote full and open competition, consistent with the OECD (2009) conventions, even during a pandemic. For example, given the failures of the Strategic National Stockpile, where supply vulnerabilities added to the poor federal 
response, considerations should be given to the SNS moving from the just-in-time approach to a just-in-case approach for inventory management. In addition, while beyond the scope of the current analysis, closer examination of the nine different solicitation procedures available to federal contractors is appropriate. For instance, while strict sealed bidding comprises less than one-half of $1 \%$ of federal contracts so is of little overall consequence, the 19.1 percentage point difference in negotiated proposals/quotes cited earlier is surely of interest. Moreover, single source contracts and those subject to multiple award fair opportunities exhibit substantial differences during COVID-19 compared to normal circumstances. Thus, it would also be fruitful to investigate individual federal contracting officer's preferences for promoting competition by determining if they actually received multiple quotes when using the SAP during the COVID-19 pandemic as well as examining the strengths and weaknesses associated with in-shoring essential PPE rather than off-shoring those critical items.

Given the dearth of data analyses in the literature on emergency procurement processes, this article calls for additional studies to determine if non-competitive contracting increases during disasters in general, and how this might compare to the unprecedented COVID-19 experience. For example, a first exploration into other disasters, such as hurricanes, could compare how goods and services were procured during those times and compare the results to COVID-19. Indeed, the authors have already begun to compare federal contracting during four major hurricanes with COVID-19 contracts, and preliminary pooled results suggest that across these four hurricanes, competitive contracting diminished even more than what has been documented here during COVID-19.

Another route for opportunistic research could examine federal contracting during disasters to see if there are patterns based on which agencies are buying and when. Returning to the preliminary pooled analysis of the four hurricanes, the lead agency (in terms of number of contracts with $38.2 \%$ ) was the Federal Emergency Management Agency while for COVID-19 federal contracts, the lead agency is the Federal Acquisition Service with $34.3 \%$ of contracts procured. Given the differing nature of disasters, perhaps this might be expected, but surely there are numerous questions left unanswered concerning this research agenda. Finally, further research might also examine distributional contracting across congressional districts to confirm if at this level, district party affiliation is associated with amounts spent, among other variables. Moreover, the analysis provided here suggests future inclusion of a number of control variables, such as an urban-rural dichotomy, race and ethnicity, and income level.

Above all, this research strongly suggests the need to more fully understand what happens in public procurement during disasters because admittedly at this time, little scientific scholarly effort has focused on this important subject. Given the huge gap in the literature, it is unknown at this time whether the empirical data outlined here are consistent with best practices during normal circumstances or not. It is easy to hypothesize that competition is expected to decline during a disaster, and this article documents this happening in the U.S. But for what period of time can this remain reasonable? One month or two; six months or one year? All of this is unknown and supports the calls for research outlined above.

What is known is that there are documented failures in terms of U.S. preparation and procurement policy response to a pandemic for which there had been many warnings issued. Unfortunately, a major takeaway is that a hyper-polarized political environment laid the 
foundation in which any procurement difficulties must be understood. Indeed, the COVID-19 crisis of U.S. emergency management has been a slow-moving train wreck that unsurprisingly turned an emergent virus into a U.S. disaster. The rise of something like COVID-19 was entirely predictable (see Garrett 1994), yet this article provides researchers with a framework to ponder how it turned into one of the greatest governance failures in U.S. history. Emergency public procurement practices are typically designed as an a priori tool to assist in on-the-ground preparations and that, under extreme circumstances, the federal government would then provide fail-safe operations to help relieve localized burdens and problems. But when an international pandemic arrives on a country's shores, the COVID-19 experience has shown that while public procurement can be a powerful and important tool in a policy response, for good or ill, it is constrained by a nation's political system.

\section{References}

AJMC. (2020). A Timeline of COVID-19 Developments in 2020. Accessed on 10 December, 2020 at https://www.ajmc.com/view/a-timeline-of-covid19-developments-in-2020

Alexander, K. (2020). I was a military COVID planner. Trust me: Texas is in Deep, Deep trouble. The Daily Beast. Accessed on 13 November 2020 at https://www.thedailybeast.com/i-was-amilitary-covid-planner-trust-me-texas-is-in-deep-deep-trouble?ref=home

Atkinson, C., McCue, C., Prier, E., and Atkinson, A. (2020). Supply chain manipulation, misrepresentation, and magical thinking during the COVID-19 pandemic. American Review of Public Administration. 50(6-7): pp. 628-634.

Bekker, M., Ivankovic, D., \& Biermann, O. (2020). Early lessons from COVID-19 response and shifts in authority: Public trust, policy legitimacy and political inclusion. European Journal of Public Health, 30(5), 854-855.

Buor, J. K. (2019). Appraising the interactions between public-sector procurement policy and disaster preparedness. International Journal of Disaster Risk Reduction, 36, 101120, 1-11. DOI 10.1016/j.ijdrr.2019.101120.

Cairney, P., \& Wellstead, A. (2020). COVID-19: Effective policymaking depends on trust in experts, politicians, and the public. Policy Design and Practice, 1-14.

Centers for Disease Control and Prevention [CDC]. (2020). United States COVID-19 Cases and Deaths by State. Accessed on 16 December 2020 at https://covid.cdc.gov/covid-datatracker/\#cases_casesper100klast7days

Center on Budget and Policy Priorities [CBPP]. (2020). States Grappling with Hit to Tax Collections. Accessed on 17 November 2020 at https://www.cbpp.org/research/state-budget-andtax/states-grappling-with-hit-to-tax-collections

Central Intelligence Agency. (2000). "National Intelligence Estimate: The Global Infectious Disease Threat and Its Implications for the United States.". Accessed 17 December 2020 at https://www.dni.gov/files/documents/infectiousdiseases_2000.pdf

Chanley, V. A., Rudolph, T. J., \& Rahn, W. M. (2000). The origins and consequences of public trust in government: A time series analysis. Public opinion quarterly, 64(3), 239-256

Chanley, V. A. (2002). Trust in Government in the Aftermath of 9/11: Determinants and Consequences. Political psychology, 23(3), 469-483. 
Chicago Sun-Times. (April 15, 2020). 80 more deaths, 1,346 new cases, as Gov. Pritzker outlines state's coronavirus budget mess, Retrieved December 19, 2020 from https://chicago.suntimes.com/coronavirus/2020/4/15/21222617/illinois-coronavirus-cases-deathsapril-15-pritzker-budget.

Citrin, J. (1974). Comment: The political relevance of trust in government. American Political Science Review, 68, 973-988.

Clemens, J. P., \& Veuger, S. (2020). Implications of the Covid-19 pandemic for state government tax revenues. NBER Working Paper, (w27426).

Clemens, J. P. (2012). State fiscal adjustment during times of stress: possible causes of the severity and composition of budget cuts. Available at SSRN 2170557.

[CNN]. (2020). Federal officials repeatedly warned that US hospitals lacked enough ventilators. Accessed on 16 December 2020 at https://www.cnn.com/2020/03/27/cnn10/ventilators-supplygovernment-warnings-coronavirus-invs/index.html

Cooper, J. (2018). Congress and the decline of public trust. Routledge.

Drezner, Daniel. (2017). The Ideas Industry: How Pessimists, Partisans, and Plutocrats are Transforming the Marketplace of Ideas. New York: Oxford University Press.

Esbitt, D. (2003). The Strategic National Stockpile: roles and responsibilities of health care professionals for receiving the stockpile assets. Disaster Management \& Response, 1(3), 68-70.

Garrett, L. (1994). The Coming Plague: Newly Emerging Diseases in a World Out of Balance. New York: Farrar, Straus and Giroux.

Gauchat, G. (2012). Politicization of science in the public sphere: A study of public trust in the United States, 1974 to 2010. American sociological review, 772), 167-187.

Gereffi, G. (2020). What does the COVID-19 pandemic teach us about global value chains? The case of medical supplies. Journal of International Business Policy, 3(3), 287-301.

Gerstein, D. M. (2020). The Strategic National Stockpile and COVID-19: Rethinking the Stockpile, Santa Monica, Calif.: RAND Corporation, CT-A530-1, 2020. Accessed on 20 December 2020: https://www.rand.org/pubs/testimonies/CTA530-1.html

Global Health Security Index [GHSI]. (2019). Global Health Security Index project. Accessed on 14 November 2020 at https://www.ghsindex.org/wp-content/uploads/2019/10/Global-HealthSecurity-Index-2019-Final-October-2019.zip

Gordon, T., Dadayan, L., \& Rueben, K. (2020). State and local government finances in the COVID19 era. National Tax Journal, 73(3), 733-757.

Gore, D. (2020). Trump Falsely claims he inherited "empty" stockpile." FactCheck.org. Accessed on 16 December 2020 at https://www.factcheck.org/2020/04/trump-falsely-claims-he-inheritedempty-stockpile/

Grossman, G., Kim, S., Rexer, J., \& Thirumurthy, H. (2020). Political partisanship influences behavioral responses to governors' recommendations for COVID-19 prevention in the United States. Available at SSRN 3578695. 
Handfield, R., Finkenstadt, D. J., Schneller, E. S., Godfrey, A. B., \& Guinto, P. (2020). A Commons for a Supply Chain in the Post-COVID-19 Era: The Case for a Reformed Strategic National Stockpile. The Milbank Quarterly.

Hanitzsch, T., Van Dalen, A., \& Steindl, N. (2018). Caught in the nexus: A comparative and longitudinal analysis of public trust in the press. The International Journal of Press/Politics, 23(1), 3-23.

Hayek, F. (1945). The Use of Knowledge in Society. American Economic Review, 35(4), 19-530.

Huntington, S. P. (1981). American Politics: The Promise of Disharmony. Cambridge, MA.: Belknap Press.

Klein, Ezra. (2020). Why We're Polarized. New York: Simon \& Schuster.

Keele, L. (2005). The authorities really do matter: Party control and trust in government. The Journal of Politics, 67(3), 873-886.

Kettl, D. F. (2020). States Divided: The Implications of American Federalism for Covid-19. Public Administration Review, 80(4), 595-602.

Kiousis, S. (2001). Public trust or mistrust? Perceptions of media credibility in the information age. Mass communication \& society, 4(4), 381-403.

Lang, J. T., and Hallman, W. K. (2005). "Who does the public trust? The case of genetically modified food in the United States." Risk Analysis: An International Journal, 25(5): 1241-1252.

Lazonick, W., \& Hopkins, M. (2020). How "Maximizing Shareholder Value" Minimized the Strategic National Stockpile: The $\$ 5.3$ Trillion Question for Pandemic Preparedness Raised by the Ventilator Fiasco. Institute for New Economic Thinking Working Paper Series, (127).

Legislative Analyst's Office [LAO]. (2020). Budget and Policy Post: COVID-19. Accessed on November 172020 at https://lao.ca.gov/Publications/Report/4292

Locht C. (2020). Vaccines against COVID-19. Anaesthesia, Critical Care \& Pain Medicine, 39(6), 703-705.

Miller, A. H. (1974a). Political issues and trust in government: 1964-1970. American Political Science Review, 68, 951-972.

Miller, A. H. (1974b). Rejoinder to "Comment" by Jack Citrin: Political discontent or ritualism? American Political Science Review, 68, 989-1001.

Miller, D. S. (2016). Public trust in the aftermath of natural and technological disasters. International Journal of Sociology and Social Polic, 36(5/6). 410-431.

Nichols, T. (2017). The Death of Expertise: The Campaign Against Established Knowledge and Why it Matters. New York: Oxford University Press.

Noll, B.A., \& Grab, D.A. (2017). Deregulation: Process and Procedures That Govern Agency Decision-making in An Era of Rollbacks. The Energy Law Journal, 38, 269-295.

Nyhan, B. (2020). Facts and myths about misperceptions. Journal of Economic Perspectives, 34(3), 220-36.

OECD (2009). OECD Principles for Integrity in Public Procurement. OECD Publishing. Accessed on 20 December 2020 at https://www.oecd.org/gov/ethics/48994520.pdf 
OECD (2020), Trust in government. OECD Publishing. Accessed on 20 December 2020 at https://data.oecd.org/gga/general-government-spending.htm\#indicator-chart

Office of Press Secretary. (2020). "Remarks by President Trump, Vice President Pence, and Members of the Coronavirus Task Force in Press Briefing." April 10, 2020. Accessed on December 29, 2020 at https://www.whitehouse.gov/briefings-statements/remarks-president-trump-vicepresident-pence-members-coronavirus-task-force-press-briefing-24/

Pew 2020a, Positive Economic Views Plummet; Support for Government Aid Crosses Party Lines: Most expect problems from COVID-19 to last six months or longer. (Pew APRIL 21, 2020). Accessed on 14 November 2020 at https://www.pewresearch.org/politics/2020/04/21/positiveeconomic-views-plummet-support-for-government-aid-crosses-party-lines/

Pew 2020b, Republicans, Democrats Move Even Further Apart in Coronavirus Concerns: Growing share of Republicans say 'the worst is behind us'. (Pew JUNE 25, 2020). Accessed on 14 November 2020 at https://www.pewresearch.org/politics/2020/06/25/republicans-democrats-move- evenfurther-apart-in-coronavirus-concerns/pp_covid-concerns-by-party_0-01/

Pew 2019. Accessed on 14 Nov. 2020 at https://www.pewresearch.org/politics/2019/04/11/publictrust-in-government-1958-2019/

Poppo, L., \& Schepker, D. J. (2010). Repairing public trust in organizations. Corporate Reputation Review, 13(2), 124-141.

Prier, E., McCue C.P, and Boykin, E. (forthcoming 2021). Assessing European Union Standardization: A Descriptive Analysis of Voluntary Ex-Ante Transparency Notices. Journal of Public Procurement.

Public Broadcasting Station, Frontline [PBS]. (2020). America's Medical Supply Crisis. Accessed on 14 November 2020 at https://www.pbs.org/wgbh/frontline/film/americas-medical-supply-crisis/ Public Health Emergency [PHE]. (2020). About the Strategic National Stockpile from the United States Department of Health \& Human Resources in the Office of the Assistant Secretary for Preparedness and Response. Accessed on 14 November 2020 at https://www.phe.gov/about/sns/Pages/about.aspx

Office of Press Secretary. (2020). "Remarks by President Trump, Vice President Pence, and Members of the Coronavirus Task Force in Press Briefing." April 10, 2020. Accessed on December 29, 2020 at https://www.whitehouse.gov/briefings-statements/remarks-president-trump-vicepresident-pence-members-coronavirus-task-force-press-briefing-24/

Reinhardt, G. Y. (2019). The Intersectionality of Disasters' Effects on Trust in Public Officials. Social Science Quarterly, 100(7), 2567-2580.

Rocco, P., Béland, D., \& Waddan, A. (2020). Stuck in neutral? Federalism, policy instruments, and counter-cyclical responses to COVID-19 in the United States. Policy and Society, 39(3), 458-477

Rudolph, T. J., \& Evans, J. (2005). Political trust, ideology, and public support for government spending. American Journal of Political Science, 49(3), 660-671.

Schapper, P. R., Malta, J. N. V., \& Gilbert, D. L. (2006). An analytical framework for the management and reform of public procurement. Journal of public procurement. 6(1\&3), 1-26.

Shearman \& Sterling. (2020). Congress passes largest ever economic stimulus package: key provisions of CARES Act. Accessed on 14 December 2020 at 
https://www.shearman.com/perspectives/2020/03/congress-passes-largest-ever-economicstimulus-package-key-provisions-of-cares-act-covid-19

Shockley-Zalabak, P. S., \& Morreale, S. P. (2020). Voters' Perceptions of Trust in Donald Trump in 2016 and 2019: Implications for Presidential Leadership in the Crises of 2020. American Behavioral Scientist. https://doi.org/10.1177/0002764220975051

Sudhi Seshadri. (2005). Sourcing Strategy: Principles, Policy and Designs. Springer, U.S.

Swire, B., Berinsky, A.J., Lewandowsky, S., and Ecker, U. K.H. (2017). "Processing Political Misinformation: Comprehending the Trump Phenomenon." Royal Society Open Science 4 (3). 121.

Thompson, B. (1988). Misuse of Chi-Square Contingency-Table Test Statistics. Educational and Psychological Research 8(1): 39-49.

Towler, C., Crawford, N., and Bennett, R. (2020). Shut Up and Play: Black Athletes, Protest Politics, and Black Political Action. Perspectives on Politics, 18(1), 111-127.

United States' Government Accountability Office Report to Congressional Requesters [GAO]. (2008). Emergency Preparedness: states are planning for medical surge, but could benefit from shared guidance for allocating scarce medical resources. Accessed on December 162020 at https://www.gao.gov/new.items/d08668.pdf

Van de Walle, S., Van Roosbroek, S., \& Bouckaert, G. (2008). Trust in the public sector: is there any evidence for a long-term decline? International Review of Administrative Sciences, 74(1), 4764.

Vecchi, V., Cusumano, N., and Boyer, E. (2020). Medical Supply Acquisition in Italy and the United States in the Era of COVID-19: The Case for Strategic Procurement and Public-Private Partnerships. The American Review of Public Administration, 50(6-7), 642-649.

Weixel, N. (2020). Trump Administration Changes Definition of National Stockpile After Kushner Remarks. The Hill. Accessed on 18 November 2020 at https://thehill.com/homenews/administration/491037-trump-administration-changes-definitionof-national-stockpile-after

WHO 2017. World Health Organization Global Health Expenditure database. Accessed on 14 November 2020 http://api.worldbank.org/v2/en/indicator/SH.XPD.GHED.PP.CD?downloadformat=excel.

Wall Street Journal [WSJ]. (2020). New face masks relieve pressure on N95 supplies. Accessed on 14 December 2020 at https://www.wsj.com/articles/new-face-masks-relievepressure-on-n95-supplies-11606386602?st=mbsosy6tvnf34tk\&reflink=article_email_share

Woodard, C. (2012). American Nations: A History of the Eleven Rival Regional Cultures of North America. New York: Penguin.

Xu, H. D., \& Basu, R. (2020). How the United States Flunked the COVID-19 test: some observations and several lessons. The American Review of Public Administration, 5066-7), 568576. 